\title{
Household survey data for research on well-being and behavior in Central Asia
}

\author{
Tilman Brück ${ }^{\mathrm{d}, \mathrm{e}}$, Damir Esenaliev ${ }^{\mathrm{a}, \mathrm{b}}$, Antje Kroeger ${ }^{\mathrm{a}, \mathrm{b}}$, Alma Kudebayeva ${ }^{\mathrm{b}, \mathrm{c}}$, \\ Bakhrom Mirkasimov ${ }^{\mathrm{a}, \mathrm{b}}$, Susan Steiner ${ }^{\mathrm{b}, \mathrm{e}, \mathrm{f}, *}$ \\ ${ }^{a}$ Humboldt-University of Berlin, Unter den Linden 6, 10099 Berlin, Germany \\ ${ }^{\mathrm{b}}$ DIW Berlin, Mohrenstr. 58, 10117 Berlin, Germany \\ ${ }^{\mathrm{c}}$ KIMEP University, 2 Abay Avenue, 050010 Almaty, Kazakhstan \\ ${ }^{\mathrm{d}}$ Stockholm International Peace Research Institute (SIPRI), Signalistgatan 9, 16970 Solna, Sweden \\ ${ }^{\mathrm{e}}$ Institute for the Study of Labor (IZA), Schaumburg-Lippe-Str. 5-9, 53113 Bonn, Germany \\ f Leibniz University Hannover, Königsworther Platz 1, 30167 Hannover, Germany
}

\section{A R T I C L E I N F O}

\section{Article history:}

Received 10 November 2012

Revised 12 February 2013

Available online 4 March 2013

\section{JEL classification:}

012

I32

J22

\section{Keywords:}

Survey data

Poverty

Labor force participation

Central Asia

\begin{abstract}
A B S T R A C T
Brück, Tilman, Esenaliev, Damir, Kroeger, Antje, Kudebayeva, Alma, Mirkasimov, Bakhrom, and Steiner, Susan-Household survey data for research on well-being and behavior in Central Asia

This paper summarizes the micro-level survey evidence from Central Asia generated and analyzed in the period 1991-2012. We provide an exhaustive overview over all accessible individual and household-level surveys undertaken in Kazakhstan, Kyrgyzstan, Tajikistan, Turkmenistan and Uzbekistan - and of all academic papers published using these datasets. We argue that Central Asia is a fascinating region for the study of comparative economics given its dual experience of transition and development. However, the region is also understudied, in part due to lack of data, and especially due to a lack of panel data. We identify knowledge gaps derived from this lack of longitudinal surveys and suggest worthwhile areas for future research. Finally, we also present a new and novel individual-level panel dataset called "Life in Kyrgyzstan". Journal of Comparative Economics 42 (3) (2014) 819-835. Humboldt-University of Berlin, Unter den Linden 6, 10099 Berlin, Germany; DIW Berlin, Mohrenstr. 58, 10117 Berlin, Germany; KIMEP University, 2 Abay Avenue, 050010 Almaty, Kazakhstan; Stockholm International Peace Research Institute (SIPRI), Signalistgatan 9, 16970 Solna, Sweden; Institute for the Study of Labor (IZA), Schaumburg-Lippe-Str. 5-9, 53113 Bonn, Germany; Leibniz University Hannover, Königsworther Platz 1, 30167 Hannover, Germany.

(c) 2013 Association for Comparative Economic Studies Published by Elsevier Inc. All rights
\end{abstract} reserved.

\section{Introduction}

Central Asia is a fascinating but vastly understudied region for comparative economic research. This paper will defend this assertion and provide an overview of existing individual and household-level surveys and corresponding research from Kazakhstan, Kyrgyzstan, Tajikistan, Turkmenistan and Uzbekistan. It will also identify research gaps that can be addressed with emerging panel data from the region, such as the "Life in Kyrgyzstan" panel survey.

Central Asia is interesting from an institutional perspective as the Soviet Union significantly shaped this region, perhaps much more so than the relatively more developed parts of (Western) Russia, leading to the establishment of far reaching

\footnotetext{
* Corresponding author. Fax: +49 5117622667.

E-mail address: steiner@ifgb.uni-hannover.de (S. Steiner).
} 
institutions of governance, transport, social infrastructure, and gender relations, to name but a few. With the dissolution of the Soviet Union, some of these institutions and achievements remained or evolved - while others declined, were abolished or destroyed. As with other countries affected by the collapse of the Soviet Union, output dropped significantly, patterns of production shifted dramatically and labor churned. From an economic development perspective, these changes may have led to greater efficiency - yet they also caused significant human hardship and violent conflict in some instances. In contrast, as Table 1 indicates, economic equality, life expectancy, and educational attainments of women are very high in Central Asia.

Perhaps up to this point the story is broadly in line with that of the Central and Eastern European transition countries. The additional twist in Central Asia, however, is that Kyrgyzstan, Tajikistan, and Uzbekistan experienced levels of output and well-being akin to low income countries in Sub-Saharan Africa and elsewhere; while Turkmenistan and Kazakhstan exhibit higher levels of GDP per capita (see Table 1). In contrast to many post-colonial Sub-Saharan African countries in the 1960s and 1970s, Central Asia, in part as the result of being part of the Silk Road, was exposed to a much faster pace of globalization (even if some Central Asian governments have chosen to respond by isolation rather than international economic engagement). Hence since independence from the Soviet Union, the Central Asian region experienced a unique combination of post-socialist transition, weak economic development, and, for some countries, rapid globalization.

These factors combine to yield exciting research questions. For example, how have people in Central Asia coped with the changes in labor market structures? What are the implications of the transition for poverty dynamics? What drives entrepreneurship and self-employment? How do gender relations and intra-household allocations respond to changing institutions and opportunities? And, importantly, what are the causes and effects of the massive scale of both international and domestic migration that has taken place in the region?

Yet these exciting research opportunities are only being realized at a very slow pace. In fact, Central Asia appears vastly understudied compared to other world regions across all disciplines. Searching the term "Central Asia" returns far fewer hits on Google Scholar (namely approximately 626,000, accessed on 7 November 2012) than "Central Europe” (1,179,000), “Central America" (1,240,000), "Middle East" (1,700,000), "Europe” (1,800,000), or "North America” (2,040,000). Furthermore, both the number of surveys and the level of survey-based, English-language, peer-reviewed research vary across Central Asia (see Table 2). In the 1991-2012 period, there are about seven times more surveys per capita and survey-based papers per capita in Kyrgyzstan than in Uzbekistan (the best and worst surveyed and researched countries per capita in the region, respectively, with the exception of Turkmenistan, for which we cannot locate any research papers). Interestingly, the productivity in terms of papers per survey is quite constant across Central Asia (except Turkmenistan) with two papers per survey, suggesting that surveys are analyzed uniformly, if not very thoroughly.

In micro-economics, at least, we posit that this dearth of research on Central Asia is due in large part to a lack of accessible and useful primary survey data, with a particular lack of micro-level panel data. Naturally, there are many reasons for this

Table 1

Selected development indicators. Source: World Development Indicators (accessed 9 November 2012).

\begin{tabular}{|c|c|c|c|c|c|c|}
\hline & Kazakhstan & Kyrgyzstan & Tajikistan & Turkmenistan & Uzbekistan & $\begin{array}{l}\text { Low income } \\
\text { countries }\end{array}$ \\
\hline Population $(1,000,000)$ & 16.6 & 5.5 & 7.0 & 5.1 & 29.3 & 816.8 \\
\hline Population growth rate (annual\%) & 1.4 & 1.1 & 1.4 & 1.2 & 2.7 & 2.1 \\
\hline Fertility rate (births per woman) & 2.6 & 2.9 & 3.2 & 2.4 & 2.5 & 4.1 \\
\hline Rural population (\% of total population) & 46.4 & 64.6 & 73.4 & 51.3 & 63.8 & 72.0 \\
\hline GDP per capita (current US\$) & 11,245 & 1075 & 935 & 4722 & 1546 & 581 \\
\hline $\begin{array}{l}\text { Poverty headcount at national poverty line } \\
\text { (\% of population) }\end{array}$ & 8.2 & 33.7 & 46.7 & - & - & - \\
\hline GINI index & 29.0 & 26.2 & 30.8 & - & - & - \\
\hline Life expectancy at birth (years) & 68.3 & 69.4 & 67.5 & 65.0 & 68.0 & 58.8 \\
\hline $\begin{array}{l}\text { Literacy rate, adult female (\% of population aged } \\
15 \text { and above) }\end{array}$ & 99.6 & 99.0 & 99.6 & 99.4 & 99.1 & 56.4 \\
\hline Secondary school enrolment, female (\% gross) & 98.3 & 83.5 & 80.9 & - & 104.5 & 38.5 \\
\hline
\end{tabular}

Note: The figures relate to the most recent year for which data were available in the WDI database.

Table 2

Micro-level surveys and corresponding publications on Central Asia. Source: Own calculations.

\begin{tabular}{|c|c|c|c|c|c|c|}
\hline & Population size (Mio) & Surveys & Surveys per $1,000,000$ & Papers & Papers per $1,000,000$ & Papers per survey \\
\hline Kazakhstan & 16.6 & 11 & 0.7 & 21 & 1.3 & 1.9 \\
\hline Kyrgyzstan & 5.5 & 14 & 2.5 & 29 & 5.3 & 2.1 \\
\hline Tajikistan & 7.0 & 11 & 1.6 & 21 & 3.0 & 1.9 \\
\hline Turkmenistan & 5.1 & 5 & 1.0 & 0 & 0.0 & 0.0 \\
\hline Uzbekistan & 29.3 & 10 & 0.3 & 20 & 0.7 & 2.0 \\
\hline Central Asia & 63.5 & 46 & 0.7 & 58 & 0.9 & 1.3 \\
\hline
\end{tabular}

Notes: For the individual countries, we counted the existing surveys per country and the corresponding papers that used those surveys, as presented in Appendix A. Surveys that include more than one country were counted separately for each country. Surveys covering more than 1 year were counted as one survey. The data covers the period 1991-2012. Papers that used survey data from more than one country were counted for each country separately. 
lack of data, including a lack of funding, a lack of capacity to conduct such surveys and analyze the resulting data, and the lack of political freedom necessary to conduct primary research. However, we also argue and demonstrate that these constraints can be, and are being, overcome, offering many new opportunities for research at the intersection of transition and development.

Central Asia is a fascinating region to study for one more reason, namely the high degree of heterogeneity between and within the Central Asian states. Mountainous terrain imposing exogenous trade barriers, different ethnicities, languages and, to a smaller extent, religions (some of which were forcefully mixed together during the Soviet period), different forms of governance, and different resource endowments ensure a high degree of variability, which appears underexploited, if only from a methodological point of view. We also wish to draw attention to the extreme differences in the availability of data and analyses across the Central Asian states. For example, Turkmenistan is a very closed and inaccessible country, with huge obstacles for the conduct of empirically based micro-level research.

The heterogeneity of country characteristics is also important from a policy perspective. Although evidence based policy making in Central Asia is not well known or widely practiced (Falkingham, 1999), if taken seriously, it would require fine grained data permitting the tracing of policy impacts across various population sub-groups. In some countries, the strong statistical capacities that exist at the central level (and which are a legacy of the Soviet times) are often used primarily for the collection of extremely detailed household budget surveys (Blank and Grosh, 1999; Esenaliev et al., 2011). These surveys are technically advanced but rarely useful, even if available, for academic analyses. Furthermore, the statistical capacities to collect these data may be strong but with a history of data being analyzed in the core, the periphery of the former Soviet Union does not have strong analytical capacities. Overall, there is then a clear need for research and policy making for more and better micro-level socio-economic data, including panel data, from Central Asia.

In this paper, we assess the current availability of micro-level surveys on Central Asia and the corresponding research output (in Section 2), demonstrating with two examples the limitations of currently available data and the potential for advances in research if more panel survey data were available. We discuss in Section 3 both of these points with regard to household well-being and household behavior, specifically poverty and female labor supply. Section 4 provides concluding remarks. As a service to the community, in Appendix A, we insert a list of all known and available micro-level surveys since 1991 for each of the five Central Asian states, as well as research contributions published in English-language academic journals or books actively using these datasets (excluding policy reports and working papers). In Appendix B, we describe the only publicly accessible, individual-level panel dataset in any Central Asian state, the "Life in Kyrgyzstan" survey.

\section{Micro-level datasets in Central Asia}

In this section, we summarize micro-level datasets in the five Central Asian countries from the dissolution of the Soviet Union in 1991 through the end of 2012. ${ }^{1}$ We restrict ourselves to individual or household surveys (hence, no enterprise surveys are included), which include at least 1000 observations $^{2}$ and for which we had sufficient information. In Tables A1-A5 of the Appendix A, we provide an overview of these surveys, separately for each one of the five countries. This overview is complete and correct to the best of our knowledge. However, dealing with a region that has changed rapidly over the past two decades and that has only recently made information openly available, some of the information provided here may be outdated or incomplete (especially for the early years of transition).

It is evident that a substantial number of surveys have been conducted in Central Asia, most by international organizations or national statistical agencies. Kyrgyzstan appears to be the country with the largest number of surveys, while only few surveys have been run in Turkmenistan. This pattern reflects the fact that the first country offers favorable conditions for collecting data and conducting research, whereas doing research on and in Turkmenistan is extremely difficult. None of the datasets collected in Turkmenistan are available to researchers and, hence, no academic articles have been produced on the basis of these datasets. Data availability is an issue in the other countries as well. Some surveys have never been shared with the research community, as shown by the lack of academic output. Given that survey data collection incurs high costs, it is desirable that surveys be regarded more as public goods and, consequently, shared with interested researchers and policy analysts.

The vast majority of Central Asian surveys are single cross-sections. There are a number of repeated cross-sections, for example the Living Standards Measurement Study (LSMS) surveys conducted in Kyrgyzstan during the 1990s or the Life in Transition surveys conducted in 2006 and 2010 across all Central Asian countries except Turkmenistan. Very little panel data, i.e. data that are collected from the same households or individuals at different points in time, have been gathered. The household budget surveys and the labor force surveys, conducted by respective national statistical agencies, are usually (rotating) household panels. ${ }^{3}$ However, our experience, from working with some of these surveys, is not too promising in terms of studying households' well-being and behavior over time. This is because the surveys include a limited range of topics, lack unique individual identifiers, and, in some cases, even lack unique household identifiers. For example, the Kyrgyz Integrated Household Survey (KIHS), which is the successor survey of the Household Budget Survey in Kyrgyzstan, collects very detailed information on household consumption and expenditure (Esenaliev et al., 2011). Every household fills in a diary on food

\footnotetext{
1 An earlier review of datasets for all transition countries, including those of Central Asia, can be found in Filer and Hanousek (2002).

2 For some surveys, we do not know the exact sample size. We list them nevertheless when we are confident that there are at least 1000 households covered.

${ }^{3}$ A rotating panel survey is a survey in which a designated proportion of the respondents is replaced in each wave.
} 
consumption, covering more than 150 food items, for 2 weeks during each quarter of the year. In addition, information on expenditure for non-food items and services is collected during quarterly interviews. However, other topics, such as migration and remittances, which are highly relevant for a household's level of well-being in Kyrgyzstan, are covered only to a limited extent.

An additional problem with the KIHS is that it does not contain unique individual identifying codes, which is necessary for studying dynamics at the individual level (for example, labor force participation or life satisfaction). Individuals are simply numbered serially in each household, which may give the same individual code to different individuals, if there are changes in household composition over time. In order to build a panel dataset at the individual level, however, it would be necessary to identify the same individuals over time. This is here possible only through merging datasets of different time periods based on household codes and time-invariant individual characteristics, such as gender and birth year. Yet, such an approach leaves substantial room for mistakes (for example, in the case of twins).

The Kazakh Household Budget Survey is similar to the KIHS with regard to the limited number of topics and the lack of unique individual identifiers, but it comes with an important additional weakness. Given that it is a rotating panel, a certain number of households leave the sample each year and new households join. Those that join are not assigned new household identifying numbers but are simply re-assigned the household codes of households that have left the sample. Essentially, this means that the panel aspect of the survey is of little use, or, if used (for example by matching households based on timeinvariant variables), is likely to bring about considerable mistakes.

Different from household budget surveys and labor force surveys, we are aware of three additional panel surveys: the Uzbekistan Regional Panel Survey (URPS) of 2005, the Tajikistan Living Standards Survey (TLSS) of 2007 and 2009 (and an extension in 2011), and the Life in Kyrgyzstan (LiK) survey of 2010-2012. The URPS collected data at three points in time in 2005 and therefore covers a short period of time, which is most likely too short to study major changes in well-being and behavior of households. It is also not nationally representative but is restricted to Kashkadarya and Andijan oblasts as well as the city of Tashkent. The 2009 TLSS re-interviewed 1500 households from the 2007 TLSS. These were also interviewed in 2011 in the so-called Migration and Remittances in Tajikistan Survey, which extends the panel to three waves and 5 years of coverage. The TLSS, with its 2011 extension, covers a wide range of topics and allows for uniquely identifying households as well as individuals within these households over time. Hence, it avoids all the major weaknesses of the household budget surveys and labor force surveys from the region, which makes it an excellent survey to study the dynamics of well-being and behavior in Tajikistan.

The LiK is a survey conducted by the authors of this paper as part of the research project "Economic Transformation, Household Behavior and Well-Being in Central Asia: The Case of Kyrgyzstan", which is funded by the Volkswagen Foundation. ${ }^{4}$ The LiK is a multi-purpose, socio-economic survey covering a wide range of topics for economic and sociological research. Its principal objective is to provide data for the analysis of well-being and behavior of individuals and households. The data is broad enough to allow for different measures of well-being, such as, for example, income, child health, or life satisfaction. Two waves of the survey have been completed so far and the third wave is ongoing at the time of writing this paper in November 2012. The LiK is nationally representative for Kyrgyzstan.

Unlike the TLSS, the LiK is an individual panel, not a household panel. This means that all adult members of the sampled households, not just one respondent, are interviewed and tracked over time. This implies that if a member of an original sample household leaves the household (e.g. to form an own family), she is still part of the sample. If relevant, other members (e.g. spouse and children) of the new household are then included in the sample as well. Having a panel at the individual level is crucial for the dynamic analysis of well-being and behavior at the individual level and for focusing on specific population sub-groups, for example women or the elderly. In the first year of the LiK (2010), more than 8000 adult individuals in 3000 households were interviewed. In the following year, $90 \%$ of these individuals were re-interviewed.

\section{What we know from panel data and what we do not know about well-being and behavior in Central Asia}

Why are we concerned with the availability of panel data? What makes panel data better than cross-sectional data? Or, in other words, what can we study with the help of panel data that is impossible to analyze with cross-sections? In this section, we answer these questions vis-à-vis Central Asia and summarize the literature that studies well-being and behavior in Central Asia and that uses survey data in order to do so. We do not provide a full literature review but, instead, restrict ourselves to the topics of poverty, one example of well-being, and female labor force participation, one example of behavior. We show that, even though the literature has brought important, policy-relevant insights, the scope of investigation has been limited to static analyses. We point out major knowledge gaps resulting from the use of cross-sectional data and identify a number of key issues that could be studied with the use of panel data.

\subsection{Poverty}

In the early years of transition from a planned to a market economy, living standards in Central Asia deteriorated sharply and poverty increased. ${ }^{5}$ Kyrgyzstan, for example, experienced a rise in the poverty headcount from $40 \%$ in 1993 , i.e. before

\footnotetext{
4 Appendix B provides a detailed description of the LiK.

${ }^{5}$ This is, of course, also true for other transition countries. How transition affected poverty has been studied, for example, by Brück et al. (2010).
} 
significant economic transformation had taken place, to 55\% in 1998, i.e. when the transition to a market economy was ongoing. The headcount subsequently dropped to $37 \%$ in 2011. The other countries have seen a similar poverty trend, although it was not in all cases as pronounced as in Kyrgyzstan (and Tajikistan). In the resource rich countries of Kazakhstan, Turkmenistan, and Uzbekistan, the poverty headcount did not increase to similarly high levels and, most importantly, is much lower today. In Kazakhstan, for example, less than $7 \%$ of the population lived below the poverty line in $2011 .^{6}$

While the profile and the determinants of poverty, or welfare more broadly, have occupied a central place in the microlevel analysis of well-being in the region, most of the attention has been paid to the relatively poorer countries of Kyrgyzstan and Tajikistan. Using LSMS data from 1993, Ackland and Falkingham (1997) determine a poverty profile for Kyrgyzstan. Female headed households, households headed by a pensioner, and households with many children are found to be particularly vulnerable to poverty. Based on cross-sectional LSMS surveys in Kyrgyzstan, Anderson and Pomfret (2000) study changes in the determinants of household expenditure between 1993 and 1996 . They find that education, location of the household, ethnicity, and household size were all important determinants of household expenditure. According to this study, college education has become an important factor in moving the living standard of households upward, and the cost of dependents has increased. Similar determinants of household welfare are found by Anderson and Pomfret (2002, 2003a, 2005), using LSMS data for Kazakhstan and Tajikistan and comparable data for Uzbekistan. In all these countries, the geographic location of the household, household composition, and education of the household head play the largest roles in determining household expenditures. Rhoe et al. (2008), based on the 1996 Kazakhstan LSMS survey, again confirm the same factors to be the main determinants of poverty in Kazakhstan. In addition to the national-level approaches, Anderson and Pomfret (2003a, 2005) compare living standards in similar locations across different countries by studying the case of the Fergana valley which lies in Kyrgyzstan, Tajikistan and Uzbekistan. The results are similar to the national results.

Even though these contributions provide a good insight into the main correlates of welfare in Central Asia (except for the case of Turkmenistan, for which we have no information), they do not shed light on the dynamics of poverty. They do not provide information on how many households are persistently poor and how many households move into and out of poverty over time. The above mentioned recent decline in the poverty headcount in Kyrgyzstan, for example, does not necessarily mean that there was a widespread improvement in living standards. It could instead be that while some households climbed out of poverty, others that were not poor at the end of the 1990s have fallen into poverty since then. Research on poverty dynamics in other developing and transition countries generally finds that there is a great deal of economic mobility over time and that transient poverty accounts for a large share of total poverty (for example, Dercon and Krishnan, 2000 on Ethiopia, Glewwe et al., 2002 on Vietnam, Jalan and Ravallion, 2000 on China, Krishna and Shariff, 2011 on India, Lokshin and Popkin, 1999 on Russia, McColluch and Baulch, 2000 on Pakistan, Radeny et al., 2012 on Kenya).

In a recent study, Bierbaum and Gassmann (2012) investigate chronic and transitory poverty in Kyrgyzstan, making use of the KIHS. However, the authors do not rely on the panel component of this dataset, because there are concerns over attrition bias. Instead, they build a so-called synthetic panel for the time period 2005-2010, which means that they predict consumption in 2005 for those households that are observed in 2010. They find that there is substantial economic mobility over this time period, even though it seems that there is much more upward than downward mobility. For the 2008-2010 period, however, when there was a dramatic increase in food and fuel prices as well as a global economic and financial crisis, Bierbaum and Gassmann show that there are equally many households moving out of and falling into poverty. The authors decompose chronic poverty across different population sub-groups and find that there is substantially more chronic poverty in rural areas, in mountainous regions, among large households, and among households with heads that have only secondary education and that work in the informal sector. This implies that the profile of the chronic poor is not much different from that of the poor, as shown above.

There is one other contribution that intends to move from static poverty analysis to a more dynamic approach: Using LSMS data, Jha and Dang (2009) analyze vulnerability to poverty in Kazakhstan, Kyrgyzstan, and Tajikistan. They define vulnerability as the probability observed today of being in poverty in the future. Vulnerability is estimated based on current realizations of consumption, assuming a stationary environment, as the underlying survey data is cross-sectional. They estimate consumption functions and predict consumption levels for the households in the samples. Depending on whether or not the predicted consumption is below or above the national poverty line, households are classified as vulnerable or nonvulnerable. Even though it is important to start taking vulnerability (and not only poverty) into account, the specific method used here, and any exercise that relies on cross-sectional data, leaves room for substantial mistakes. The problem is that the current consumption level of some households may be low because they suffer from temporary hardship. In other years, these households may not have low consumption and should thus not be categorized as vulnerable. The opposite is also true. Some households may be considered as non-vulnerable, if their current level of consumption is temporarily high due to favorable short-term conditions but they actually are vulnerable.

Neither Bierbaum and Gassmann (2012) nor Jha and Dang (2009) can provide insights into what determines potential movements into and out of poverty. Given that geographic location of households has turned out to be an essential determinant of current living standards in several Central Asian countries, it would be interesting to know, for example, whether migration from rural to urban areas can mitigate poverty. It could be that households were able to move out of poverty

\footnotetext{
${ }^{6}$ These numbers are different from those in Table 1, because they are based on publications by the respective national statistical agencies. We did not rely on the World Development Indicators here because these do not report poverty headcounts before 2001 for Kazakhstan and 2006 for Kyrgyzstan.
} 
simply by relocating to the capital city because the rates of return to their assets could be much higher there than in the village. In contrast, it could also be that households born in different geographic locations accumulate different types as well as different levels of assets, so that migration would not necessarily lead to an escape from poverty if different (levels of) assets were required in the capital city.

Unless we have more information about poverty dynamics, it is difficult to draw adequate conclusions for policy-making. First, as explained above, the identification of the poor may be difficult when only cross-sectional data is available. Governments interested in targeting specific programs to the poor may then make substantial errors of inclusion (i.e. targeting to households that are categorized as poor in the period of data collection but that are non-poor in other time periods) as well as errors of exclusion (i.e. targeting to households that are categorized as non-poor in the period of data collection but that are poor in other time periods). Second, Addison et al. (2009) describe that policy responses to chronic poverty may be very different from policy responses to transitory poverty. While unemployment insurance, microcredit, and temporary social safety nets may be adequate in the latter case, the former case requires responses that include providing access to health and education services as well as asset redistribution.

Third, policy interventions that help people climb out of poverty may be completely different from interventions designed to help them avoid falling into poverty, since factors for escaping from and descending into poverty differ. Krishna (2006) shows for villages in Andhra Pradesh, India, that health and health-related expenses, high interest on private debt, social expenses for marriages and funerals, drought, large family size, and a combination of these constitute factors leading households into poverty, whereas pathways out of poverty include job creation, diversification in income creation, and irrigation. Related to this, knowing more about poverty dynamics is also important for measuring the impact of public policy. For example, changes to social assistance programs (such as the Unified Monthly Benefit in Kyrgyzstan) are generally motivated by the aim to better target the poor. Determination of whether or not this is achieved requires observation of the same households over time.

\subsection{Female labor force participation}

Under the Soviet rule, the Central Asian region underwent an intensive process of modernization and dynamic transformation, including the establishment of gender equality before the law and universal access to basic health care and education services (Akiner, 1997; Paci, 2002). There were improvements for women in the range of occupational choices, greater visibility in public life, equal access to education and health as well as relatively high female labor force participation. However, gender equality was only partially achieved. In addition to being active in the labor market, women remained the main providers of care for the household; their total time commitment to household and formal work was very high. Family and community relations were reportedly the most conservative areas of the society with powerful extended family networks and hierarchical structures (Akiner, 1997).

After the dissolution of the Soviet Union, the extensive socioeconomic transformation in Central Asia not only affected the structure of the economy, the living standards of the population, and the labor markets (Lehmann and Muravyev, forthcoming), but also the prevailing gender relations (Paci, 2002). For example, the secular tradition during the Soviet period has faced the re-emergence of many Islamic traditions, which usually includes a more conservative stance towards the role of women in the economy. The impact of this social transition is yet to be determined (Akiner, 1997; Heyat, 2004). ADB (2006: xi) reports that gender "stereotypes reinforce discriminatory practices in the workplace, leaving women without employment in higher-paid and skilled sectors and consequently withdrawing from the formal workforce." Falkingham (2001) finds that girls are increasingly facing discrimination in access to health and education in Tajikistan. Yet, gender inequality can be a significant constraint to economic growth (Klasen and Lamanna, 2009; Knowles et al., 2002).

Against this background, while it is vital to study women's behavior on the labor market since the Soviet Union dissolved, not much attention has actually been paid to this topic. One of the few academic outputs focusing specifically on female labor supply in Central Asia is Anderson and Pomfret (2003b), using 1993 and 1997 LSMS data for Kyrgyzstan. The authors show that labor force participation decreased for both men and women in the early years of transition: from $77.4 \%$ in 1993 to $65.8 \%$ in 1997 for men, and from $57.5 \%$ to $44.3 \%$ over the same period for women. Babetskii et al. (2003) report that these numbers remained constant between 1997 and 2000. Anderson and Pomfret (2003b) estimate labor force participation models, which confirm that women were less likely than men to be in the work force. Yet, the marginal effect of gender decreased between 1993 and 1997. The main gender dimensions of labor force participation, shown by the authors, are marriage, young children, and education. Marriage and young children reduce female labor force participation, but their effect also decreases over time. This implies that young married mothers do not substitute time spent at home for time in the workplace, which is surprising given the drastic decline in kindergarten facilities during transition. Education has a much higher effect on labor force participation for women than for men, and mostly for individuals with higher education. College educated women are found to have responded to transition with disproportionately greater labor force participation than any other population group.

Consistent with the evidence in European transition countries, the authors also find that the gender difference in terms of hours worked, wage rates, and monthly earnings decreased between 1993 and 1997. This finding is explained by the increased returns to education (which have allowed educated women to earn as much as men), a decreased gap in the hours of work, and a narrowed unexplained wage gap between men and women (which possibly has to do with less discrimination of women in the market system compared with the earlier planned economy). All of these are important insights on how 
transition affected women on the labor market in Kyrgyzstan. However, they are based on data from 1993 to 1997; which are probably no longer accurate. Furthermore, they are restricted to one country, and we know little about whether or not the other Central Asian countries had or have similar patterns and determinants of female labor force participation. As is wellknown, Kyrgyzstan is the most reformist country in the region, and it may well be that the situation for women on the labor market is very different in the other countries. Verme (2001) provides some limited insights for Kazakhstan. He shows that women experience reduced income in the state sector and are less likely to be self-employed than men. Tajikistan, with its 1992-1998 civil war, may be a special case. As Shemyakina (2011) shows, the war had persistent negative consequences for the education of girls. It is unknown how this translated into female labor force participation after the war ended. And last, but not least, we know nothing about the dynamics of family interaction and work, as no panel data have been applied in the analysis of female labor force participation. We return to this issue below.

Building on Anderson and Pomfret (2003b), we identify three additional factors that may be important for the work decisions of women in the Central Asian context that have not sufficiently been addressed in the literature. First, co-residence of adult children with elderly parents and different arrangements for the care of elderly and children may substantially affect female labor force participation. On the one hand, co-residence with an older generation may reduce the labor supply of women because younger women are usually the ones taking care of co-resident elderly family members. On the other hand, coresident elderly family members often take care of their grandchildren, which may facilitate the labor force participation of women, as found for some European countries (Zamarro, 2011). Magnani and Rammohan (2009) examine the impact of caregiving for elderly household members on the labor force participation of younger adult household members in Indonesia. They find that care-giving reduces both the intensive as well as extensive margins of labor supply, and that this effect is stronger for females than for males. Ardington et al. (2009) find that in South Africa labor supply (i.e. labor migration) of adult daughters rises with the pension receipt of grandmothers because grandmothers provide both regular income and child care. For urban China, Liu et al. (2010) show that caring for parents does not affect women's labor supply, whereas caring for parents-in-law has a negative effect on women's labor force participation and hours of work. This latter result is particularly interesting for the societies of Central Asia, where patrilocality is practiced. This means that women usually leave their parents to live with their parents-in-law at the time of marriage.

Second, international migration of household members is likely to influence female labor force participation, especially in Kyrgyzstan, Tajikistan and Uzbekistan - three countries with substantial numbers of labor migrants. The preponderance of evidence from migrant sending countries seems to point to a decline in labor force participation for women as a consequence of migration of other household members (Acosta, 2006; Amuedo-Dorantes and Pozo, 2006; Lokshin and Glinskaya, 2009; Mendola and Carletto, 2012; Rodriguez and Tiongson, 2001). The common explanation is that migration brings remittance income, which increases the reservation wage of those left behind, thus leading to a decline in labor supply. For the case of Central Asia, Justino and Shemyakina (2010) shed some light on this issue and find that Tajik women from remittancereceiving households are less likely to participate in the labor force and to supply fewer work hours compared with women from households that do not receive remittances. Shahriari et al. (2009) focus on women's access to land in Tajikistan and show that female-headed households with migrant status rent more land than female-headed households without migrants. This may imply that migration increases the economic activity of members of female-headed households in the agricultural market. However, whether or not these are the females themselves and whether and how other household members change their labor supply in response to migration remains unclear in this contribution. Further research on the impact of migration on women's labor supply decisions in Central Asia can shed more light onto this and similar questions.

Third, the association between individuals' attitudes on gender roles and the labor force participation of women is a highly promising area of research. Based on Australian survey data, Vella (1994) compares two groups - females with "modern" attitudes and females with "traditional" attitudes - and finds that the former group is more likely to invest in human capital and participate on the labor market. Fortin (2005), using the World Values Survey across 25 countries, concludes that "anti-egalitarian" attitudes toward gender roles have the strongest negative association with female employment rates in OECD countries. She also confirms that views on traditional gender roles are strongly influenced by religious ideology. Antecol (2003), using data from the International Social Survey Programme, finds that females are more likely to work if men are in favor of women working outside of the home. Contreras and Plaza (2010), using data from the same program, find that women with conservative values are less likely to participate on the labor market in Chile. In the Central Asian context, religion plays an increasingly important role in the division of labor within the household and the weights placed on the preferences of household members.

We argue that knowing more about these potential determinants of female labor force participation would considerably enhance our understanding of the socio-economic living conditions of women in Central Asia. Including co-residence, migration, and gender attitudes in labor supply models, using cross-sectional data, would already be a first step. Ideally, however, such models would be estimated with the use of panel data. This would reduce potential heterogeneity bias in the estimates and would help to draw conclusions for causality. Heterogeneity bias arises when unobserved characteristics of individuals are correlated with observed characteristics as well as the outcome variable. In the context of migration, for example, it is very likely that a household's (observable) decision to send a migrant abroad is not exogenously given, but is determined by the extent of the household members' (unobservable) motivation and ability. The coefficient on migration in the female labor force participation model would then pick up the effect of motivation and ability and not necessarily the effect of migration. If the same households and individuals were observed over time, changes in labor force participation could be more 
reliably traced back to changes in the migration status of households, because the presumably time-invariant level of motivation and ability of household members would be identical before and after migration.

Finally, as in the case of poverty analysis, having panel data also helps to measure the impact of public policy on female labor force participation. One current matter that comes to mind is the common economic space of Belarus, Russia, and Kazakhstan, which was launched in January 2012. Kyrgyzstan and Tajikistan are likely to join in the near future. This common economic space will have profound effects on the production structure, employment, and prices in the member countries, and it is today unclear what its impact on female labor force participation will be.

\section{Conclusion}

With this survey, we wish to draw attention to the opportunities for micro-level comparative economic research on and in Central Asia. We identify many existing cross-sectional datasets that appear to remain underexploited. We also introduce a novel individual panel survey from Kyrgyzstan called "Life in Kyrgyzstan", which provides open access data for academic research and policy analyses. With such innovations in research infrastructure, we expect the level and quality of quantitative, micro-level, empirical, academic research to improve in the future. This will be interesting intellectually - and possible lay the foundation for more evidence-based policy making in Central Asia. The more liberal countries of Central Asia may see an especially large improvement in local research capacity that is able to conduct and exploit such quantitative studies. International donors may support these processes by providing long-term funding for civil society led research infrastructure - and by supporting more access to official data sharing. Similarly, governments and donors could ask for and fund more randomized controlled trials and other robust evaluation techniques that will help generate further data and understanding of the rapid socio-economic changes experienced across Central Asia.

\section{Acknowledgments}

Financial support from the Volkswagen Foundation is gratefully acknowledged. The authors would like to thank Kerstin Ringelhan, Martin Wiegand and Marina Wulff for excellent research assistance in the elaboration of the tables.

\section{Appendix A}

See Tables A1-A5.

Table A1

Household surveys in Kazakhstan, 1991-2012.

\begin{tabular}{|c|c|c|c|c|c|c|}
\hline Survey name & Agency & Type & Years & Availability & $\begin{array}{l}\text { No. of } \\
\text { households }\end{array}$ & $\begin{array}{l}\text { Academic output using these } \\
\text { data }\end{array}$ \\
\hline \multirow[t]{2}{*}{$\begin{array}{l}\text { Demographic and Health } \\
\text { Survey }\end{array}$} & $\begin{array}{l}\text { USAID/Academy of Preventive } \\
\text { Medicine }\end{array}$ & $\begin{array}{l}\text { Cross- } \\
\text { section }\end{array}$ & 1995 & Yes & 4178 & $\begin{array}{l}\text { Agadjanian (1999), Agadjanian } \\
\text { et al. (2008), Agadjanian and } \\
\text { Qian (1997) and Aleshina and } \\
\text { Redmond (2005) }\end{array}$ \\
\hline & $\begin{array}{l}\text { USAID/National Institute of } \\
\text { Nutrition }\end{array}$ & $\begin{array}{l}\text { Cross- } \\
\text { section }\end{array}$ & 1999 & Yes & 5844 & $\begin{array}{l}\text { Agadjanian et al. (2008), } \\
\text { Aleshina and Redmond (2005) } \\
\text { and Buckley et al. (2008) }\end{array}$ \\
\hline $\begin{array}{l}\text { Global Youth Tobacco } \\
\text { Survey }\end{array}$ & $\begin{array}{l}\text { Centers for Disease Control and } \\
\text { Prevention/WHO/UNICEF }\end{array}$ & $\begin{array}{l}\text { Cross- } \\
\text { section }\end{array}$ & 2004 & Yes & n.a. & \\
\hline $\begin{array}{l}\text { Household Budget Survey } \\
\text { (HBS) }\end{array}$ & $\begin{array}{l}\text { Agency of the Republic of } \\
\text { Kazakhstan on Statistics }\end{array}$ & $\begin{array}{l}\text { Rotating } \\
\text { panel }\end{array}$ & $\begin{array}{l}2001- \\
2012\end{array}$ & $\begin{array}{l}\text { Yes, for a } \\
\text { fee }\end{array}$ & 12,000 & $\begin{array}{l}\text { Arabsheibani and Mussurov } \\
\text { (2007), Kalyuzhnova and } \\
\text { Kambhampati (2007) and Verme } \\
(2006,2010)\end{array}$ \\
\hline \multirow[t]{2}{*}{ Labor Force Survey } & \multirow[t]{2}{*}{$\begin{array}{l}\text { Agency of the Republic of } \\
\text { Kazakhstan on Statistics }\end{array}$} & $\begin{array}{l}\text { Cross- } \\
\text { section }\end{array}$ & 1994 & No & 3526 & \multirow[t]{2}{*}{$\begin{array}{l}\text { Klugman and Scott (1997) and } \\
\text { Klugman et al. (1997) }\end{array}$} \\
\hline & & $\begin{array}{l}\text { Rotating } \\
\text { panel }\end{array}$ & $\begin{array}{l}2001- \\
2012\end{array}$ & $\begin{array}{l}\text { Yes, for a } \\
\text { fee }\end{array}$ & 21,000 & \\
\hline $\begin{array}{l}\text { Life in Transition Survey } \\
\quad \text { (LITS) }\end{array}$ & $\begin{array}{l}\text { European Bank for } \\
\text { Reconstruction and } \\
\text { Development/World Bank }\end{array}$ & $\begin{array}{l}\text { Cross- } \\
\text { section }\end{array}$ & $\begin{array}{l}2006 \\
2010\end{array}$ & Yes & 1000 & \\
\hline $\begin{array}{l}\text { Living Standards } \\
\text { Measurement Survey } \\
\text { (LSMS) }\end{array}$ & $\begin{array}{l}\text { Agency of the Republic of } \\
\text { Kazakhstan on Statistics/World } \\
\text { Bank }\end{array}$ & $\begin{array}{l}\text { Cross- } \\
\text { section }\end{array}$ & 1996 & Yes & 1996 & $\begin{array}{l}\text { Anderson and Pomfret (2002, } \\
\text { 2003a, 2005), Jha and Dang } \\
\text { (2009), Kalyuzhnova and } \\
\text { Kambhampati (2008), Rhoe et al. } \\
\text { (2008), Sari (2004) and Verme } \\
\text { (2000) }\end{array}$ \\
\hline
\end{tabular}


Table A1 (continued)

\begin{tabular}{|c|c|c|c|c|c|c|}
\hline Survey name & Agency & Type & Years & Availability & $\begin{array}{l}\text { No. of } \\
\text { households }\end{array}$ & $\begin{array}{l}\text { Academic output using these } \\
\text { data }\end{array}$ \\
\hline $\begin{array}{l}\text { Migration and Remittances } \\
\text { in Kazakhstan }\end{array}$ & $\begin{array}{l}\text { Institute for East and Southeast } \\
\text { European Studies Regensburg/ } \\
\text { CIOM Almaty }\end{array}$ & $\begin{array}{l}\text { Cross- } \\
\text { section }\end{array}$ & 2010 & Not yet & 2227 & \\
\hline \multirow[t]{2}{*}{$\begin{array}{l}\text { Multiple Indicator Cluster } \\
\text { Survey }\end{array}$} & $\begin{array}{l}\text { Agency of the Republic of } \\
\text { Kazakhstan on Statistics/UNICEF }\end{array}$ & $\begin{array}{l}\text { Cross- } \\
\text { section }\end{array}$ & 2006 & Yes & 15,000 & \\
\hline & & $\begin{array}{l}\text { Cross- } \\
\text { section }\end{array}$ & $\begin{array}{l}2010 / \\
11\end{array}$ & Not yet & n.a. & \\
\hline Remittance Senders Survey & Asian Development Bank & $\begin{array}{l}\text { Cross- } \\
\text { section }\end{array}$ & 2007 & No & 1185 & \\
\hline $\begin{array}{l}\text { Survey of Conflict } \\
\text { Prevention and } \\
\text { Cooperation }\end{array}$ & $\begin{array}{l}\text { The Brookings Institution/World } \\
\text { Bank }\end{array}$ & $\begin{array}{l}\text { Cross- } \\
\text { section }\end{array}$ & 2004 & Yes & 1500 & \\
\hline \multirow[t]{2}{*}{ World Health Survey } & World Health Organization & $\begin{array}{l}\text { Cross- } \\
\text { section }\end{array}$ & 2002 & Yes & 4499 & \\
\hline & & & 2003 & Yes & 2894 & \\
\hline
\end{tabular}

Note: Availability usually means that the data can be obtained after registration with the respective agency. n.a. = information not available. The academic output is restricted to English-language contributions published in academic journals or books. Policy reports and working papers are not included. It also considers only those articles that report on analysis of the data, disregarding articles that merely refer to statistics based on these data.

Table A2

Household surveys in Kyrgyzstan, 1991-2012.

\begin{tabular}{|c|c|c|c|c|c|c|}
\hline Survey name & Agency & Type & Years & Availability & $\begin{array}{l}\text { No. of } \\
\text { households }\end{array}$ & $\begin{array}{l}\text { Academic output using these } \\
\text { data }\end{array}$ \\
\hline \multirow[t]{2}{*}{$\begin{array}{l}\text { Demographic and Health } \\
\text { Survey (DHS) }\end{array}$} & $\begin{array}{l}\text { USAID/Ministry of Health/ } \\
\text { Institute of Obstetrics and } \\
\text { Pediatrics }\end{array}$ & $\begin{array}{l}\text { Cross- } \\
\text { section }\end{array}$ & 1997 & Yes & 3672 & Aleshina and Redmond (2005) \\
\hline & $\begin{array}{l}\text { USAID/Ministry of Health/ } \\
\text { National Statistical } \\
\text { Committee of the Kyrgyz } \\
\text { Republic }\end{array}$ & $\begin{array}{l}\text { Cross- } \\
\text { section }\end{array}$ & 2012 & Not yet & 9500 & \\
\hline $\begin{array}{l}\text { Global Youth Tobacco } \\
\text { Survey }\end{array}$ & $\begin{array}{l}\text { World Health Organization/ } \\
\text { Centers for Disease Control } \\
\text { and Prevention }\end{array}$ & $\begin{array}{l}\text { Cross- } \\
\text { section }\end{array}$ & $\begin{array}{l}2004 \\
2008\end{array}$ & Yes & 4270 & \\
\hline $\begin{array}{l}\text { Household Budget Survey } \\
\text { (HBS) }\end{array}$ & $\begin{array}{l}\text { National Statistical } \\
\text { Committee of the Kyrgyz } \\
\text { Republic }\end{array}$ & $\begin{array}{l}\text { Rotating } \\
\text { panel }\end{array}$ & $\begin{array}{l}1996- \\
2003\end{array}$ & No & $1000-3000$ & $\begin{array}{l}\text { Baschieri and Falkingham } \\
\text { (2006), Kudabaev and Minbaev } \\
\text { (2003) and Savastano and } \\
\text { Scandizzo (2009) }\end{array}$ \\
\hline Household Energy Survey & $\begin{array}{l}\text { National Statistical } \\
\text { Committee of the Kyrgyz } \\
\text { Republic }\end{array}$ & $\begin{array}{l}\text { Cross- } \\
\text { section }\end{array}$ & 1999 & No & 3006 & \\
\hline $\begin{array}{l}\text { Household Survey on } \\
\text { Remittances and Poverty }\end{array}$ & $\begin{array}{l}\text { Asian Development Bank/ } \\
\text { CASE-Kyrgyzstan }\end{array}$ & $\begin{array}{l}\text { Cross- } \\
\text { section }\end{array}$ & 2007 & No & 3995 & $\begin{array}{l}\text { Atamanov and van den Berg } \\
(2012 a)\end{array}$ \\
\hline $\begin{array}{l}\text { Kyrgyz Integrated } \\
\text { Household Survey (KIHS) }\end{array}$ & $\begin{array}{l}\text { National Statistical } \\
\text { Committee of the Kyrgyz } \\
\text { Republic }\end{array}$ & $\begin{array}{l}\text { Rotating } \\
\text { panel }\end{array}$ & $\begin{array}{l}2003- \\
2012\end{array}$ & $\begin{array}{l}\text { Yes, for a } \\
\text { fee }\end{array}$ & 5000 & $\begin{array}{l}\text { Atamanov and van den Berg } \\
\text { (2012b) and Falkingham et al. } \\
(2010)\end{array}$ \\
\hline Life in Kyrgyzstan (LiK) & $\begin{array}{l}\text { German Institute for } \\
\text { Economic Research/CASE- } \\
\text { Kyrgyzstan }\end{array}$ & Panel & $\begin{array}{l}2010- \\
2012\end{array}$ & $\begin{array}{l}\text { Yes, for a } \\
\text { fee }\end{array}$ & 3000 & \\
\hline $\begin{array}{l}\text { Life in Transition Survey } \\
\quad \text { (LITS) }\end{array}$ & $\begin{array}{l}\text { European Bank for } \\
\text { Reconstruction and } \\
\text { Development/World Bank }\end{array}$ & $\begin{array}{l}\text { Cross- } \\
\text { section }\end{array}$ & $\begin{array}{l}2006 \\
2010\end{array}$ & Yes & 1000 & \\
\hline $\begin{array}{l}\text { LSMS - Kyrgyz } \\
\text { Multipurpose Poverty } \\
\text { Study (KMPS) }\end{array}$ & $\begin{array}{l}\text { World Bank/National } \\
\text { Statistical Committee of the } \\
\text { Kyrgyz Republic }\end{array}$ & $\begin{array}{l}\text { Cross- } \\
\text { section }\end{array}$ & 1993 & Yes & 2000 & $\begin{array}{l}\text { Ackland and Falkingham (1997), } \\
\text { Anderson and Becker (1999), } \\
\text { Anderson and Pomfret (2000, } \\
\text { 2002, 2003a, 2005), Babu and } \\
\text { Reidhead (2000), Falkingham } \\
\text { (1997), Giddings et al. (2007) } \\
\text { and Namazie and Sanfey (2001) }\end{array}$ \\
\hline $\begin{array}{l}\text { LSMS - Kyrgyz Poverty } \\
\text { Monitoring Survey } \\
\text { (KPMS) }\end{array}$ & $\begin{array}{l}\text { World Bank/National } \\
\text { Statistical Committee of the } \\
\text { Kyrgyz Republic }\end{array}$ & $\begin{array}{l}\text { Cross- } \\
\text { section }\end{array}$ & $\begin{array}{l}1996 \\
\text { (two } \\
\text { rounds) }\end{array}$ & Yes & 1951 & $\begin{array}{l}\text { Anderson and Becker (1999), } \\
\text { Anderson and Pomfret (2000, } \\
\text { 2003a) and Bernabé and Kolev } \\
\text { (2005) }\end{array}$ \\
\hline
\end{tabular}


Table A2 (continued)

\begin{tabular}{|c|c|c|c|c|c|c|}
\hline Survey name & Agency & Type & Years & Availability & $\begin{array}{l}\text { No. of } \\
\text { households }\end{array}$ & $\begin{array}{l}\text { Academic output using these } \\
\text { data }\end{array}$ \\
\hline & $\begin{array}{l}\text { World Bank/National } \\
\text { Statistical Committee of the } \\
\text { Kyrgyz Republic }\end{array}$ & $\begin{array}{l}\text { Cross- } \\
\text { section }\end{array}$ & 1997 & Yes & 2604 & $\begin{array}{l}\text { Anderson and Pomfret (2002, } \\
\text { 2003a, 2005), Babu and } \\
\text { Reidhead (2000) and Bernabé } \\
\text { and Kolev (2005) }\end{array}$ \\
\hline & $\begin{array}{l}\text { World Bank/National } \\
\text { Statistical Committee of the } \\
\text { Kyrgyz Republic }\end{array}$ & $\begin{array}{l}\text { Cross- } \\
\text { section }\end{array}$ & 1998 & Yes & 2979 & $\begin{array}{l}\text { Bernabé and Kolev (2005), } \\
\text { Giddings et al. (2007) and Jha } \\
\text { and Dang (2009) }\end{array}$ \\
\hline $\begin{array}{l}\text { Multiple Indicator Cluster } \\
\text { Survey (MICS) }\end{array}$ & $\begin{array}{l}\text { National Statistical } \\
\text { Committee of the Kyrgyz } \\
\text { Republic/UNICEF }\end{array}$ & $\begin{array}{l}\text { Cross- } \\
\text { section }\end{array}$ & 2006 & Yes & 5179 & \\
\hline $\begin{array}{l}\text { Survey of Conflict } \\
\text { Prevention and } \\
\text { Cooperation }\end{array}$ & $\begin{array}{l}\text { The Brookings Institution/ } \\
\text { World Bank }\end{array}$ & $\begin{array}{l}\text { Cross- } \\
\text { section }\end{array}$ & 2004 & Yes & 1500 & \\
\hline $\begin{array}{l}\text { Survey on Labor Migration } \\
\text { from Kyrgyzstan to } \\
\text { Russia }\end{array}$ & $\begin{array}{l}\text { OSCE, ACTED, European } \\
\text { Commission }\end{array}$ & $\begin{array}{l}\text { Cross- } \\
\text { section }\end{array}$ & 2009 & No & 1200 & \\
\hline World Values Survey & $\begin{array}{l}\text { World Values Survey } \\
\text { Association }\end{array}$ & $\begin{array}{l}\text { Cross- } \\
\text { section }\end{array}$ & 2003 & Yes & 1043 & \\
\hline
\end{tabular}

Note: Availability usually means that the data can be obtained after registration with the respective agency. The academic output is restricted to Englishlanguage contributions published in academic journals or books. Policy reports and working papers are not included. It also considers only those articles that report on analysis of the data, disregarding articles that merely refer to statistics based on these data.

Table A3

Household surveys in Tajikistan, 1991-2012.

\begin{tabular}{|c|c|c|c|c|c|c|}
\hline Survey name & Agency & Type & Years & Availability & $\begin{array}{l}\text { No. of } \\
\text { households }\end{array}$ & $\begin{array}{l}\text { Academic output using these } \\
\text { data }\end{array}$ \\
\hline $\begin{array}{l}\text { Demographic and } \\
\text { Health Survey } \\
\text { (DHS) }\end{array}$ & $\begin{array}{l}\text { USAID/Statistical Agency of the } \\
\text { Republic of Tajikistan }\end{array}$ & Cross-section & 2012 & Not yet & n.a. & \\
\hline $\begin{array}{l}\text { Household Budget } \\
\text { Survey (HBS) }\end{array}$ & $\begin{array}{l}\text { Statistical Agency of the } \\
\text { Republic of Tajikistan }\end{array}$ & n.a. & n.a. & No & n.a. & \\
\hline $\begin{array}{l}\text { Household Survey } \\
\text { on Remittances } \\
\text { and Poverty }\end{array}$ & Asian Development Bank & Cross-section & 2007 & No & 3300 & \\
\hline Labor Force Survey & $\begin{array}{l}\text { Statistical Agency of the } \\
\text { Republic of Tajikistan }\end{array}$ & n.a. & n.a. & No & n.a. & \\
\hline \multirow[t]{2}{*}{$\begin{array}{l}\text { Labor Migration } \\
\text { from Tajikistan }\end{array}$} & $\begin{array}{l}\text { International Organization for } \\
\text { Migration/Sharq Scientific } \\
\text { Research Center }\end{array}$ & Cross-section & 2002 & No & 2000 & \\
\hline & & & 2003 & No & 4000 & \\
\hline $\begin{array}{l}\text { Life in Transition } \\
\quad \text { Survey (LITS) }\end{array}$ & $\begin{array}{l}\text { European Bank for } \\
\text { Reconstruction and } \\
\text { Development/World Bank }\end{array}$ & Cross-section & $\begin{array}{l}2006 \\
2010\end{array}$ & Yes & 1000 & \\
\hline \multirow[t]{4}{*}{$\begin{array}{l}\text { LSMS - Tajikistan } \\
\quad \text { Living Standards } \\
\quad \text { Survey (TLSS) }\end{array}$} & $\begin{array}{l}\text { World Bank/Statistical Agency } \\
\text { of the Republic of Tajikistan }\end{array}$ & Cross-section & 1999 & Yes & 2000 & $\begin{array}{l}\text { Aleshina and Redmond (2005), } \\
\text { Anderson and Pomfret (2002, } \\
\text { 2003a, 2005), Babu and Rhoe } \\
\text { (2006), Falkingham (2004), } \\
\text { Grogan (2007), Jha and Dang } \\
\text { (2009) and Shemyakina (2011) }\end{array}$ \\
\hline & $\begin{array}{l}\text { World Bank/Statistical Agency } \\
\text { of the Republic of Tajikistan }\end{array}$ & Cross-section & 2003 & Yes & 4156 & $\begin{array}{l}\text { Falkingham (2003), Falkingham } \\
\text { and Baschieri (2009), Fan and } \\
\text { Habibov (2009), Grogan (2007), } \\
\text { Habibov (2009), Habibov and } \\
\text { Fan (2008) and Shemyakina } \\
(2011)\end{array}$ \\
\hline & $\begin{array}{l}\text { World Bank/Statistical Agency } \\
\text { of the Republic of Tajikistan }\end{array}$ & $\begin{array}{l}\text { Cross-section } \\
\text { (partly panel) }\end{array}$ & $\begin{array}{l}2007 / \\
\text { Wave } \\
1\end{array}$ & Yes & 4860 & $\begin{array}{l}\text { Azzari and Zezza (2011) and } \\
\text { Danzer and Ivaschenko (2010) }\end{array}$ \\
\hline & $\begin{array}{l}\text { World Bank/Statistical Agency } \\
\text { of the Republic of Tajikistan }\end{array}$ & Panel & $\begin{array}{l}2009 / \\
\text { Wave } \\
2\end{array}$ & Yes & 1500 & Danzer and Ivaschenko (2010) \\
\hline $\begin{array}{l}\text { Micronutrient } \\
\text { Status Survey in } \\
\text { Tajikistan } \\
\text { (MNSS-T) }\end{array}$ & UNICEF/Ministry of Health & Cross-section & $\begin{array}{l}2003 \\
2009\end{array}$ & $\begin{array}{l}\text { No } \\
\text { No }\end{array}$ & $\begin{array}{l}5232 \\
\text { individuals } \\
4320 \\
\text { individuals }\end{array}$ & \\
\hline
\end{tabular}


Table A3 (continued)

\begin{tabular}{|c|c|c|c|c|c|c|}
\hline Survey name & Agency & Type & Years & Availability & $\begin{array}{l}\text { No. of } \\
\text { households }\end{array}$ & $\begin{array}{l}\text { Academic output using these } \\
\text { data }\end{array}$ \\
\hline $\begin{array}{l}\text { Migration and } \\
\text { Remittances in } \\
\text { Tajikistan }\end{array}$ & $\begin{array}{l}\text { Institute for East and Southeast } \\
\text { European Studies Regensburg/ } \\
\text { SHARQ Dushanbe }\end{array}$ & $\begin{array}{l}\text { Panel (Re- } \\
\text { interview of TLSS } \\
2009 \text { households) }\end{array}$ & 2011 & Not yet & 1500 & \\
\hline \multirow[t]{2}{*}{$\begin{array}{l}\text { Multiple Indicator } \\
\text { Cluster Survey } \\
\text { (MICS) }\end{array}$} & $\begin{array}{l}\text { Statistical Agency of the } \\
\text { Republic of Tajikistan/UNICEF }\end{array}$ & Cross-section & 2000 & Yes & 3720 & $\begin{array}{l}\text { Aleshina and Redmond (2005), } \\
\text { Edmonds and Pavcnik (2005) } \\
\text { and Falkingham (2003) }\end{array}$ \\
\hline & $\begin{array}{l}\text { Statistical Agency of the } \\
\text { Republic of Tajikistan/UNICEF }\end{array}$ & Cross-section & 2005 & Yes & 6968 & \\
\hline $\begin{array}{l}\text { Survey of Conflict } \\
\text { Prevention and } \\
\text { Cooperation }\end{array}$ & $\begin{array}{l}\text { The Brookings Institution/ } \\
\text { World Bank }\end{array}$ & Cross-section & 2004 & Yes & 1500 & \\
\hline
\end{tabular}

Note: Availability usually means that the data can be obtained after registration with the respective agency. n.a. = information not available. The academic output is restricted to English-language contributions published in academic journals or books. Policy reports and working papers are not included. It also considers only those articles that report on analysis of the data, disregarding articles that merely refer to statistics based on these data.

Table A4

Household surveys in Turkmenistan, 1991-2012.

\begin{tabular}{|c|c|c|c|c|c|c|}
\hline Survey name & Agency & Type & Years & Availability & $\begin{array}{l}\text { No. of } \\
\text { households }\end{array}$ & $\begin{array}{l}\text { Academic output } \\
\text { using these data }\end{array}$ \\
\hline $\begin{array}{l}\text { Demographic and } \\
\text { Health Survey } \\
\text { (DHS) }\end{array}$ & $\begin{array}{l}\text { USAID/Maternal and Child Health Center/Ministry of } \\
\text { Health/Medical Industry of Turkmenistan } \mathrm{MCH} / \mathrm{MOH} / \\
\text { MIT }\end{array}$ & $\begin{array}{l}\text { Cross- } \\
\text { section }\end{array}$ & 2000 & No & 6303 & \\
\hline $\begin{array}{l}\text { Employment and } \\
\text { Labor Force Survey }\end{array}$ & $\begin{array}{l}\text { State Committee of Statistics of Turkmenistan/United } \\
\text { Nations Development Programme }\end{array}$ & $\begin{array}{l}\text { Cross- } \\
\text { section }\end{array}$ & 2001 & No & n.a. & \\
\hline Family Budget Survey & State Committee of Statistics of Turkmenistan & $\begin{array}{l}\text { Cross- } \\
\text { section }\end{array}$ & 1993 & No & n.a. & \\
\hline $\begin{array}{r}\text { Living Standards } \\
\text { Measurement }\end{array}$ & $\begin{array}{l}\text { State Committee of Statistics of Turkmenistan/World } \\
\text { Bank }\end{array}$ & $\begin{array}{l}\text { Cross- } \\
\text { section }\end{array}$ & 1998 & No & 2350 & \\
\hline \multirow[t]{2}{*}{ Survey (TLSS) } & $\begin{array}{l}\text { State Committee of Statistics of Turkmenistan/Asian } \\
\text { Development Bank }\end{array}$ & $\begin{array}{l}\text { Cross- } \\
\text { section }\end{array}$ & 2003 & No & n.a. & \\
\hline & $\begin{array}{l}\text { State Committee of Statistics of Turkmenistan/World } \\
\text { Bank }\end{array}$ & $\begin{array}{l}\text { Cross- } \\
\text { section }\end{array}$ & 2011 & No & n.a. & \\
\hline $\begin{array}{l}\text { Multiple Indicator } \\
\text { Cluster Survey } \\
\text { (MICS) }\end{array}$ & State Committee of Statistics of Turkmenistan/UNICEF & $\begin{array}{l}\text { Cross- } \\
\text { section }\end{array}$ & 2006 & No & n.a. & \\
\hline
\end{tabular}

Note: Availability usually means that the data can be obtained after registration with the respective agency. n.a. = information not available.

Table A5

Household surveys in Uzbekistan, 1991-2012.

\begin{tabular}{|c|c|c|c|c|c|c|}
\hline Survey name & Agency & Type & Years & Availability & $\begin{array}{l}\text { No. of } \\
\text { households }\end{array}$ & Academic output using these data \\
\hline $\begin{array}{l}\text { Demographic and Health } \\
\text { Survey }\end{array}$ & $\begin{array}{l}\text { USAID/Institute of } \\
\text { Obstetrics and } \\
\text { Gynecology/Ministry of } \\
\text { Health }\end{array}$ & $\begin{array}{l}\text { Cross- } \\
\text { section }\end{array}$ & 1996 & Yes & 3703 & $\begin{array}{l}\text { Aleshina and Redmond (2005), Barrett } \\
\text { and Buckley (2007), Buckley et al. (2004), } \\
\text { Falkingham (2005) and Hohmann and } \\
\text { Garenne (2010) }\end{array}$ \\
\hline $\begin{array}{l}\text { Demographic and Health } \\
\text { Survey/Uzbekistan } \\
\text { Health Examination } \\
\text { Survey (UHES) }\end{array}$ & $\begin{array}{l}\text { USAID/Ministry of Health/ } \\
\text { State Committee of the } \\
\text { Republic of Uzbekistan on } \\
\text { Statistics }\end{array}$ & $\begin{array}{l}\text { Cross- } \\
\text { section }\end{array}$ & 2002 & Yes & 4168 & $\begin{array}{l}\text { Barrett and Buckley (2007), Falkingham } \\
\text { (2005), Hadley et al. (2010) and Hohmann } \\
\text { and Garenne (2010) }\end{array}$ \\
\hline $\begin{array}{l}\text { EUI/Essex Survey in } \\
\text { Uzbekistan (EESU) }\end{array}$ & $\begin{array}{l}\text { European University } \\
\text { Institute/University of } \\
\text { Essex }\end{array}$ & $\begin{array}{l}\text { Cross- } \\
\text { section }\end{array}$ & 1995 & No & 1581 & $\begin{array}{l}\text { Anderson and Pomfret (2003a), Coudouel } \\
\text { and Marnie (1999), Coudouel et al. } \\
\text { (1997b), Hiwatari (2003) and } \\
\text { Micklewright and Ismail (2001) }\end{array}$ \\
\hline $\begin{array}{l}\text { Household Budget Survey } \\
\quad \text { (HBS) }\end{array}$ & $\begin{array}{l}\text { State Committee of the } \\
\text { Republic of Uzbekistan on } \\
\text { Statistics }\end{array}$ & n.a. & n.a. & No & $\begin{array}{l}4000- \\
10000\end{array}$ & Coudouel et al. (1997a) \\
\hline $\begin{array}{l}\text { Household budget survey } \\
\text { on "Revenues, expenses } \\
\text { and loans of people }\end{array}$ & $\begin{array}{l}\text { "Expert Fikri" Center on } \\
\text { Sociological Surveys/ } \\
\text { Japanese International }\end{array}$ & $\begin{array}{l}\text { Cross- } \\
\text { section }\end{array}$ & 2003 & No & 1000 & Hiwatari (2003) \\
\hline
\end{tabular}


Table A5 (continued)

\begin{tabular}{|c|c|c|c|c|c|c|}
\hline Survey name & Agency & Type & Years & Availability & $\begin{array}{l}\text { No. of } \\
\text { households }\end{array}$ & Academic output using these data \\
\hline $\begin{array}{l}\text { living in mahalla" } \\
\text { Labor Force Survey }\end{array}$ & $\begin{array}{l}\text { Cooperation Agency } \\
\text { Ministry of Labor and } \\
\text { Social Protection, } \\
\text { Uzbekistan/International } \\
\text { Labor Organization }\end{array}$ & n.a. & n.a. & No & 16,000 & \\
\hline $\begin{array}{l}\text { Life in Transition Survey } \\
\text { (LITS) }\end{array}$ & $\begin{array}{l}\text { European Bank for } \\
\text { Reconstruction and } \\
\text { Development/World Bank }\end{array}$ & $\begin{array}{l}\text { Cross- } \\
\text { section }\end{array}$ & $\begin{array}{l}2006 \\
2010\end{array}$ & Yes & 1000 & \\
\hline \multirow[t]{3}{*}{$\begin{array}{l}\text { Multiple Indicator Cluster } \\
\text { Survey (MICS) }\end{array}$} & $\begin{array}{l}\text { State Committee of the } \\
\text { Republic of Uzbekistan on } \\
\text { Statistics/UNICEF }\end{array}$ & $\begin{array}{l}\text { Cross- } \\
\text { section }\end{array}$ & 2000 & Yes & 5313 & $\begin{array}{l}\text { Aleshina and Redmond (2005) and Pavin } \\
\text { et al. (2003) }\end{array}$ \\
\hline & $\begin{array}{l}\text { State Committee of the } \\
\text { Republic of Uzbekistan on } \\
\text { Statistics/UNICEF }\end{array}$ & $\begin{array}{l}\text { Cross- } \\
\text { section }\end{array}$ & 2006 & Yes & 10,198 & \\
\hline & $\begin{array}{l}\text { State Committee of the } \\
\text { Republic of Uzbekistan on } \\
\text { Statistics/UNICEF }\end{array}$ & $\begin{array}{l}\text { Cross- } \\
\text { section }\end{array}$ & 2011 & Not yet & n.a. & \\
\hline $\begin{array}{l}\text { Survey of Conflict } \\
\text { Prevention and } \\
\text { Cooperation }\end{array}$ & $\begin{array}{l}\text { The Brookings Institution/ } \\
\text { World Bank }\end{array}$ & $\begin{array}{l}\text { Cross- } \\
\text { section }\end{array}$ & 2004 & Yes & 1500 & \\
\hline \multirow[t]{2}{*}{$\begin{array}{l}\text { Uzbekistan Regional Panel } \\
\text { Survey (URPS) }\end{array}$} & World Bank & $\begin{array}{l}\text { Panel } \\
(3\end{array}$ & 2005 & No & 3000 & $\begin{array}{l}\text { Parpiev and Yusupov (2011) and Parpiev } \\
\text { et al. (2012) }\end{array}$ \\
\hline & & waves) & & & & \\
\hline
\end{tabular}

Note: Availability usually means that the data can be obtained after registration with the respective agency. n.a. = information not available. The academic output is restricted to English-language contributions published in academic journals or books. Policy reports and working papers are not included. It also considers only those articles that report on analysis of the data, disregarding articles that merely refer to statistics based on these data.

\section{Appendix B}

\section{B.1. The "Life in Kyrgyzstan" (LiK) Survey}

\section{B.1.1. Background}

The LiK is conducted as a part of the "Economic Transformation, Household Behavior and Well-Being in Central Asia: The Case of Kyrgyzstan" research project that is funded by the Volkswagen Foundation. This projects aims to (1) to collect nationally representative panel survey data in Kyrgyzstan, (2) to investigate well-being and behavior of individuals and households in this country, and (3) to improve research capacity within the Central Asian region. It runs from September 2009 through September 2013 and is a collaborative endeavor of DIW Berlin, Humboldt University of Berlin, the Center for Social and Economic Research (CASE-Kyrgyzstan), and the American University of Central Asia (AUCA), the latter two being based in Bishkek, Kyrgyzstan.

It is important to note that a household is defined in the LiK as all members of a domestic unit who normally live together, eat their meals together, and share expenses. This is in line with Living Standard Measurement Study (LSMS) instructions in the region and is not trivial, as multiple family households are commonplace. In other words, households may consist of several families. They may also include individuals who are absent at the time of the survey due to study, work, or visits. This latter point is crucial as seasonal migrants may be listed as household members, even though they are abroad, if they would normally live, eat, and share the expenses with the rest of the household.

\section{B.1.2. Sampling}

The LiK collects data in all seven Kyrgyz oblasts (i.e. Batken, Chui, Djalal-Abad, Issyk-Kul, Naryn, Osh, and Talas) and the cities of Bishkek and Osh. It is representative at the national level as well as for urban and rural areas and for the south and the north of the country.

The original sample that was drawn for the first wave of data collection consists of 3000 households and slightly more than 8000 individuals in these households. The households were drawn through stratified two-stage random sampling. The strata are formed by Bishkek, Osh city, and the rural and urban areas of the seven oblasts, amounting to a total of 16 strata. At the first stage, a set of so-called population points (i.e. communities in rural areas, quarters in urban areas) were drawn in each stratum according to probabilities proportionate to population size. Table B1 provides an overview of the number of households in the total population and in the sample drawn for the first wave of the LiK. In each population point, a set of 25 households were drawn at the second stage. The National Statistical Committee (NSC) of the Kyrgyz Republic provided us with a household survey sample of 3000 households based on the 2009 Population Census data. NSC also prepared reserve samples, ranging from $20 \%$ of the sample in rural areas to $100 \%$ in violence-affected areas in the southern part of the 
Table B1

Household population in Kyrgyzstan and first-wave LiK sample. Source: The number of households in the population is from the 2009 Population Census.

\begin{tabular}{|c|c|c|c|c|c|c|}
\hline & \multicolumn{3}{|c|}{ Number of households in total population, in '000 (in \%) } & \multicolumn{3}{|c|}{ Number of households in first-wave sample (in \%) } \\
\hline & All & Urban & Rural & All & Urban & Rural \\
\hline Batken oblast & 80.1 (6.99) & $23.0(2.01)$ & $57.1(4.98)$ & $225(7.50)$ & $75(2.50)$ & $150(5.00)$ \\
\hline Chui oblast & $206.3(18.00)$ & $48.5(4.23)$ & $157.8(13.77)$ & $550(18.34)$ & $125(4.17)$ & $425(14.17)$ \\
\hline Djalal-Abad & $186.4(16.27)$ & $51.9(4.53)$ & $134.5(11.74)$ & $475(15.84)$ & $125(4.17)$ & 350 (11.67) \\
\hline Issyk-Kul oblast & $103.2(9.01)$ & 35.4 (3.09) & $67.8(5.92)$ & $275(9.16)$ & $100(3.33)$ & $175(5.83)$ \\
\hline Naryn oblast & $51.1(4.46)$ & $9.0(0.79)$ & 42.1 (3.67) & $125(4.16)$ & $25(0.83)$ & $100(3.33)$ \\
\hline Osh oblast & $187.9(16.40)$ & $15.3(1.34)$ & $172.6(15.06)$ & $475(15.83)$ & $25(0.83)$ & $450(15.00)$ \\
\hline Talas oblast & $44.2(3.86)$ & $8.4(0.73)$ & $35.8(3.13)$ & $125(4.16)$ & $25(0.83)$ & $100(3.33)$ \\
\hline Bishkek & $229.1(19.99)$ & $228.4(19.93)$ & $0.7(0.06)$ & $600(20.00)$ & $600(20.00)$ & 0 \\
\hline Osh city & $57.5(5.02)$ & $53.5(4.67)$ & $4.0(0.35)$ & $150(5.00)$ & $150(5.00)$ & 0 \\
\hline Total & $1.145 .8(100)$ & $473.4(41.32)$ & $672.4(58.68)$ & $3000(100)$ & $1250(41.66)$ & $1750(58.33)$ \\
\hline
\end{tabular}

country. As only $73 \%$ of the households on the original sample list were found and interviewed, $27 \%$ of households had to be drawn from the reserve samples. Refusal to participate was quite high: Almost two thirds of the households from the original sample list that had to be replaced had declined to participate in the survey.

\section{B.1.3. Organization of fieldwork}

The survey is implemented by the data collection company Sotseconik, which is based in Bishkek, Kyrgyzstan. The interviews are conducted by around 120 recruited interviewers, who are supervised by 40 field supervisors. The field supervisors, along with eight regional supervisors, are responsible for logistical and administrative issues, as well as for counseling and data quality checks.

A pilot survey is run about 1 month before the main survey starts in each year. It is usually conducted in Bishkek (urban population) and Chui oblast (rural population), covering a total of 30 households. Based on the pilot test results and consultations with the interviewers, the questionnaires are optimized to make them unequivocally clear. The training for all field staff consists of explaining the goals of the project, in-class study of questionnaires, and in-class exercises. During the main survey, the average workload per interviewer is approximately 25 households, but the actual time spent for interviews differs depending on the size and the situation of the household. On average, the time spent on the household questionnaire is approximately $45 \mathrm{~min}$. Individual questionnaires take about $50 \mathrm{~min}$ to complete. All interviewers and field supervisors are equipped with an interviewer manual that contains explanations of the field works process and the survey questions. Two quality checks are made at the data collection and the data entry level.

\section{B.1.4. Survey instruments}

The LiK survey consists of a household questionnaire (to be filled in by the most informed household member), an individual questionnaire (to be filled in by all adults of age 18 and above of the sampled households), and a community questionnaire (to be filled in by a representative of the local administration). Children, aged 17 and younger, do not fill out their own individual questionnaire. Information about children is collected in the household questionnaire. All questionnaires are first developed in English and are then translated into Kyrgyz and Russian. ${ }^{7}$ The interviews are conducted as paper and pencil interviews in Kyrgyz or Russian, depending on the language preference of the interviewees.

Each of the questionnaires consists of several modules, all of which have been incorporated in the first two waves of the survey and will also be included in any future waves. Most of the modules consist, in turn, of several sections. Some changes were made to the questionnaires after the first wave. A few sections were dropped because they turned out to deliver too few useful observations (for example, Employees in Agricultural Markets, and Reverse Remittances) or were no longer relevant in 2011 (for example, Displacement). A number of sections that promised to provide information on interesting and relevant topics were incorporated into the survey during the second wave (for example, Expenses on Customs and Traditions, Decision-Making, Time Use, Women's Background and Fertility). Within modules, improvements to the questions were also made, but this was kept to a minimum in order to secure comparability of the data over time. In the following, the structure of the questionnaires is presented. The italicized sections were included either in 2010 or in 2011, but not in both years.

\footnotetext{
Household questionnaire

1. Household Roster

1.1. Household Composition

1.2. Child Education

1.3. Child Health
}

(continued on next page)

\footnotetext{
${ }^{7}$ The questionnaires in all three languages can be accessed at the project website: http://www.diw.de/kyrgyzstan.
} 
2. Housing and Assets

2.1. Housing

2.2. Assets

2.3. Land

3. Agricultural Markets

3.1. Trade Activity

3.2. Employees (2010)

3.3. Quality Requirements

4. Consumption and Expenditure

4.1. Food Items

4.2. Non-Food Items

4.3. Expenses on Customs and Traditions (2011)

5. Income Sources

6. Migration

6.1. Current Labor Migration

6.2. Remittances

6.3. Reverse Remittances (2010)

7. Shocks

Individual questionnaire

1. Subjective Well-Being

2. Education and Health

2.1. Education

2.2. Health

3. Labor Market

3.1. Current Employment Status

3.2. Work during the last 7 days

3.3. Current Unemployment or Inactivity

3.4. Work during the last 12 months

3.5. Labor Market CV

4. Movements

5. Family and Household

5.1. Family

5.2. Decision Making (2011)

5.3. Time Use (2011)

5.4. Women's Background and Fertility (2011)

6. Worries

7. Security and Violence

7.1. Perception of Security

7.2. Violence

7.3. Displacement (2010)

8. Social Life

8.1. Membership in Groups

8.2. Informal Networks

8.3. Trust and Information

\section{Community questionnaire}

1. Community Information

2. Prices for Food Products

\section{B.4.1. Panel design}

In principle, all persons who took part in the first wave of the survey in 2010 are to be surveyed in the following waves. Hence, the survey tracks individuals, not households. In each survey year, all individuals aged 18 and older, who were part of an LiK household in previous years, and their respective households, are to be interviewed. If a sample individual moves, the individual is followed within Kyrgyzstan; if he or she moves out of the country, the individual is dropped from the sample. He or she may re-enter when coming back to the original household later. New individuals who move into an existing LiK household are surveyed and tracked, even in case of subsequently leaving that household, in following waves. Since all adult household members are to be re-interviewed individually in the LiK, the next generation is automatically taken into account: All children of LiK households become part of the sample when they turn 18. 
With regard to the sample sizes, 8160 individuals were interviewed in the first wave and 8066 individuals in the second wave. Of the individuals included in the first wave, 7364 (or 90.2\%) were re-interviewed during the second wave. With regard to households, 3000 households were interviewed in the first wave and 2863 in the second wave. Of the households included in the first wave, 2856 (or 95.2\%) were re-interviewed during the second wave.

\section{References}

Ackland, Robert, Falkingham, Jane, 1997. A profile of poverty in Kyrgyzstan. In: Falkingham, Jane, Klugman, Jeni, Marnie, Sheila, Micklewright, John (Eds.), Household Welfare in Central Asia. Palgrave Macmillan, Basingstoke, UK.

Acosta, Pablo, 2006. Labor Supply, School Attendance, and Remittances from International Migration: The Case of El Salvador, World Bank Policy Research Working Paper. World Bank, Washington DC.

ADB, 2006. Country Gender Assessment: Kyrgyz Republic. Asian Development Bank, Manila.

Addison, Tony, Hulme, David, Kanbur, Ravi, 2009. Poverty dynamics: measurement and understanding from an interdisciplinary perspective. In: Addison, Tony, Hulme, David, Kanbur, Ravi (Eds.), Poverty Dynamics. Interdisciplinary Perspectives. Oxford University Press, Oxford, pp. 3-26.

Agadjanian, Victor., 1999. Post-Soviet demographic paradoxes: ethnic differences in marriage and fertility in Kazakhstan. Sociological Forum 14 , 425-446. Agadjanian, Victor, Qian, Zhenchao, 1997. Ethnocultural identity and induced abortion in Kazakhstan. Studies in Family Planning $28,317$.

Agadjanian, Victor, Dommaraju, Premchand, Glick, Jennifer E., 2008. Reproduction in upheaval: ethnic-specific fertility responses to societal turbulence in Kazakhstan. Population Studies 62, 211-233.

Akiner, Shirin, 1997. Between tradition and modernity: the dilemma facing contemporary Central Asian women. In: Buckley, Mary (Ed.), Post-Soviet Women: From the Baltic to Central Asia. Cambridge University Press, Cambridge, pp. 261-304.

Aleshina, Nadezhda, Redmond, Gerry, 2005. How high is infant mortality in central and eastern Europe and the commonwealth of independent states? Population Studies 59, 39-54.

Amuedo-Dorantes, Catalina, Pozo, Susan, 2006. Migration, remittances, and male and female employment patterns. American Economic Review 96, $222-226$.

Anderson, Kathryn H., Becker, Charles M., 1999. Post-soviet pension systems, retirement, and elderly poverty: findings from the Kyrgyz Republic. MOCTMOST: Economic Policy in Transitional Economies 9, 459-478.

Anderson, Kathryn H., Pomfret, Richard, 2000. Living standards during transition to a market economy: the Kyrgyz Republic in 1993 and 1996. Journal of Comparative Economics 28, 502-523.

Anderson, Kathryn H., Pomfret, Richard, 2002. Relative living standards in new market economies: evidence from Central Asian household surveys. Journal of Comparative Economics 30, 683-708.

Anderson, Kathryn H., Pomfret, Richard, 2003a. Cross-country comparisons of the determinants of living standards. In: Anderson, Kathryn H., Pomfret, Richard (Eds.), Consequences of Creating a Market Economy: Evidence from Household Surveys in Central Asia. Edward Elgar Publishing, Cheltenham, pp. 67-93.

Anderson, Kathryn H., Pomfret, Richard, 2003b. Women in the Labour Market in the Kyrgyz Republic, 1993 and 1997. In: Anderson, Kathryn H., Pomfret, Richard (Eds.), Consequences of Creating a Market Economy: Evidence from Household Surveys in Central Asia. Edward Elgar Publishing, Cheltenham, pp. 94-140.

Anderson, Kathryn H., Pomfret, Richard, 2005. Spatial inequality and development in Central Asia. In: Venables, Anthony, Kanbur, Ravi, Wan, Guanghua (Eds.), Spatial Disparities in Human Development: Perspectives from Asia. Oxford University Press.

Antecol, Heather, 2003. Why is There Cross-Country Variation in Female Labour Force Participation Rates? The Role of Male Attitudes toward Family and Sex Roles, Claremont Colleges Working Papers. Department of Economics, Claremont McKenna College, Claremont.

Arabsheibani, G. Reza, Mussurov, Altay, 2007. Returns to schooling in Kazakhstan: OLS and instrumental variables approach. Economics of Transition 15, 341-364.

Ardington, Cally, Case, Anne, Hosegood, Victoria, 2009. Labour supply responses to large social transfers: longitudinal evidence from South Africa. American Economic Journal: Applied Economics 1, 22-48.

Atamanov, Aziz., van den Berg, Marrit., 2012a. Heterogeneous effects of international migration and remittances on crop income: evidence from the Kyrgyz Republic. World Development 40, 620-630.

Atamanov, Aziz, van den Berg, Marrit, 2012b. Participation and returns in rural nonfarm activities: evidence from the Kyrgyz Republic. Agricultural Economics 43, 459-471.

Azzari, Carlo, Zezza, Alberto, 2011. International migration and nutritional outcomes in Tajikistan. Food Policy 36, 54-70.

Babetskii, Ian, Kolev, Alexandre, Maurel, Mathilde, 2003. Kyrgyz labour market in the late 1990s: the challenge of formal job creation. Comparative Economic Studies 45, 493-519.

Babu, Suresh, Reidhead, William, 2000. Poverty, food security, and nutrition in Central Asia: a case study of the Kyrgyz Republic. Food Policy 25, 647-660.

Babu, Suresh, Rhoe, Valerie, 2006. Food security and poverty in Central Asia. In: Babu, Suresh, Djalalov, Sandjar (Eds.), Policy Reforms and Agriculture Development in Central Asia. Springer, New York.

Barrett, Jennifer, Buckley, Cynthia, 2007. Constrained contraceptive choice: IUD prevalence in Uzbekistan. International Family Planning Perspectives 33, 50-57.

Baschieri, Angela, Falkingham, Jane, 2006. Formalizing informal payments: the progress of health reform in Kyrgyzstan. Central Asian Survey 25, 441-460.

Bernabé, Sabine, Kolev, Alexandre, 2005. Jobless or working poor in the Kyrgyz Labour market: what role for social policies? Social Policy \& Administration 39, 409-430.

Bierbaum, Mira, Gassmann, Franziska, 2012. Chronic and Transitory Poverty in the Kyrgyz Republic. What can Synthetic Panels Tell us?, UNU-MERIT Working Paper Series. Maastricht University and United Nations University, Maastricht.

Blank, Lorraine, Grosh, Margaret, 1999. Using household surveys to build analytic capacity. World Bank Research Observer 14, $209-227$.

Brück, Tilman, Danzer, Alexander, Muravyev, Alexander, Weißhaar, Natalia, 2010. Poverty during transition: household survey evidence from Ukraine. Journal of Comparative Economics 38, 123-145.

Buckley, Cynthia, Barrett, Jennifer, Asminkin, Yakov P., 2004. Reproductive and sexual health among young adults in Uzbekistan. Studies in Family Planning 35, $1-14$.

Buckley, Cynthia, Barrett, Jennifer, Adkins, Kristen, 2008. Reproductive health information for young women in Kazakhstan: disparities in access by channel. Journal of Health Communication 13, 681-697.

Contreras, Dante, Plaza, Gonzalo, 2010. Cultural factors in women's labour force participation in Chile. Feminist Economics $16,27-46$.

Coudouel, Aline, Marnie, Sheila, 1999. From universal to targeted social assistance: an assessment of the Uzbek Experience. MOCT-MOST: Economic Policy in Transitional Economies 9, 443-458.

Coudouel, Aline, Marnie, Sheila, Micklewright, John, Shcherbakova, Galina, 1997a. Regional differences in living standards in Uzbekistan. In: Falkingham, Jane, Klugman, Jeni, Marnie, Sheila, Micklewright, John (Eds.), Household Welfare in Central Asia. Palgrave Macmillan, Basingstoke, UK.

Coudouel, Aline, McAuley, Alastair, Micklewright, John, 1997b. Transfers and Exchange between Households in Uzbekistan. In: Falkingham, Jane, Klugman, Jeni, Marnie, Sheila, Micklewright, John (Eds.), Household Welfare in Central Asia. Palgrave Macmillan, Basingstoke, UK.

Danzer, Alexander, Ivaschenko, Oleksiy, 2010. Migration patterns in a remittances dependent economy: evidence from Tajikistan during the global financial crisis. Migration Letters 7, 190-202.

Dercon, Stefan, Krishnan, Pramila, 2000. Vulnerability, seasonality and poverty in Ethiopia. Journal of Development Studies $36,25-53$. 
Edmonds, Eric V., Pavcnik, Nina, 2005. Child Labor in the Global Economy. Journal of Economic Perspectives 19, 199-220.

Esenaliev, Damir, Kroeger, Antje, Steiner, Susan, 2011. The Kyrgyz Integrated Household Survey (KIHS) - A Primer Data Documentation. DIW Berlin, Berlin.

Falkingham, Jane, 1997. Public transfer and targeting in Kyrgyzstan. In: Falkingham, Jane, Klugman, Jeni, Marnie, Sheila, Micklewright, John (Eds.), Household Welfare in Central Asia. Palgrave Macmillan, Basingstoke, UK.

Falkingham, Jane, 1999. Measuring household welfare: problems and pitfalls with household surveys in Central Asia. MOCT-MOST: Economic Policy in Transitional Economies 9, 379-393.

Falkingham, Jane, 2001. Women and Gender Relations in Tajikistan Country Briefing Paper. Asian Development Bank, Manila.

Falkingham, Jane, 2003. Inequality and changes in women's use of maternal health-care services in Tajikistan. Studies in Family Planning 34, 32-43.

Falkingham, Jane, 2004. Poverty, out-of-pocket payments and access to health care: evidence from Tajikistan. Social Science \& Medicine 58, 247-258.

Falkingham, Jane, 2005. The end of the rollercoaster? Growth, inequality and poverty in Central Asia and the Caucasus. Social Policy \& Administration 39, 340-360.

Falkingham, Jane, Baschieri, Angela, 2009. Gender and poverty: how misleading is the unitary model of household resources? An illustration from Tajikistan. Global Social Policy 9, 43-62.

Falkingham, Jane, Akkazieva, Baktygul, Baschieri, Angela, 2010. Trends in out-of-pocket payments for health care in Kyrgyzstan, 2001-2007. Health Policy and Planning 25, 427-436.

Fan, Lida, Habibov, Nazim N., 2009. Determinants of maternity health care utilization in Tajikistan: learning from a national living standards survey. Health \& Place 15, 952-960.

Filer, Randall K., Hanousek, Jan, 2002. Data watch: research data from transition economies. Journal of Economic Perspectives 16, 225-240.

Fortin, Nicole M., 2005. Gender role attitudes and the labor market outcomes for women across OECD countries. Oxford Review of Economic Policy 21, 416-438.

Giddings, Lisa, Meurs, Mieke, Temesgen, Tilahun, 2007. Changing preschool enrolments in post-socialist central asia: causes and implications. Comparative Economic Studies 49, 81-100.

Glewwe, Paul, Gragnolati, Michele, Zaman, Hassan, 2002. Who gained from Vietnam's boom in the 1990s? Economic Development and Cultural Change 50, 773-792.

Grogan, Louise, 2007. Patrilocality and human capital accumulation - evidence from Central Asia. Economics of Transition 15, 685-705.

Habibov, Nazim N., 2009. Determinants of out-of-pocket expenditures on prescribed medications in Tajikistan: implications for healthcare sector reform. Journal of Health Organization and Management 23, 170-182.

Habibov, Nazim N., Fan, Lida, 2008. Modelling prenatal health care utilization in Tajikistan using a two-stage approach: implications for policy and research. Health Policy and Planning 23, 443-451.

Hadley, Craig, Brewis, Alexandra, Pike, Ivy, 2010. Does less autonomy erode women's health? Yes. No. Maybe. American Journal of Human Biology 22, 103-110. Heyat, Farideh, 2004. Re-Islamisation in Kyrgyzstan: gender, new poverty and the moral dimension. Central Asian Survey 23, 275-287.

Hiwatari, Masato, 2003. Traditions and the informal economy in Uzbekistan: a case study of gaps in the Andijan region. Acta Slavica Iaponica 25, 43-66.

Hohmann, Sophie, Garenne, Michel, 2010. Health and wealth in Uzbekistan and Sub-Saharan Africa in comparative perspective. Economics and Human Biology 8, 346-360.

Jalan, Jyotsna, Ravallion, Martin, 2000. Is transient poverty different? Evidence for rural China. Journal of Development Studies 36, 82-99.

Jha, Raghbendra, Dang, Tu, 2009. Vulnerability to poverty in select Central Asian countries. European Journal of Comparative Economics 6, 17-50.

Justino, Patricia, Shemyakina, Olga, 2010. Remittances and Labour Supply in Post-Conflict Tajikistan HiCN Working Paper. Households in Conflict Network, Brighton.

Kalyuzhnova, Yelena, Kambhampati, Uma, 2007. Education or employment - choices facing young People in Kazakhstan. Journal of International Development 19, 607-626.

Kalyuzhnova, Yelena, Kambhampati, Uma, 2008. The determinants of individual happiness in Kazakhstan. Economic Systems 32, $285-299$.

Klasen, Stefan, Lamanna, Francesca, 2009. The impact of gender inequality in education and employment on economic growth: new evidence for a panel of countries. Feminist Economics 15, 91-132.

Klugman, Jeni, Scott, Kinnon, 1997. Measuring labour market status in Kazakhstan. In: Falkingham, Jane, Klugman, Jeni, Marnie, Sheila, Micklewright, John (Eds.), Household Welfare in Central Asia. Palgrave Macmillan, Basingstoke, UK.

Klugman, Jeni, Marnie, Sheila, Micklewright, John, O'Keefe, Philip, 1997. The impact of kindergarten divestiture on household welfare in Central Asia. In: Falkingham, Jane, Klugman, Jeni, Marnie, Sheila, Micklewright, John (Eds.), Household Welfare in Central Asia. Palgrave Macmillan, Basingstoke, UK.

Knowles, Stephen, Lorgelly, Paula K., Owen, P. Dorian, 2002. Are educational gender gaps a brake on economic development? Some cross-country empirical evidence. Oxford Economic Papers 54, 118-149.

Krishna, Anirudh, 2006. Pathways out of and into poverty in 36 villages of Andhra Pradesh, India. World Development 34, 271-288.

Krishna, Anirudh, Shariff, Abusaleh, 2011. The irrelevance of national strategies? Rural poverty dynamics in states and regions of India, 1993-2005. World Development 39, 533-549.

Kudabaev, Zarylbek, Minbaev, M., 2003. Poverty reduction in the Kyrgyz Republic and accuracy of measuring it. Statistical Journal of the United Nations ECE 20, 241-254.

Lehmann, Hartmut, Muravyev, Alexander, forthcoming. Labor markets and labor market institutions in transition economies. In: Hare, Paul, Turley, Gerard (Eds.), The Handbook on the Economics and Political Economy of Transition. Routledge.

Liu, Lan, Dong, Xiao-yuan, Zheng, Xiaoying, 2010. Parental care and married women's labor supply in Urban China. Feminist Economics 16, 169-192.

Lokshin, Michael, Glinskaya, Elena, 2009. The effect of male migration on employment patterns of women in Nepal. The World Bank Economic Review 23, 481-507.

Lokshin, Michael, Popkin, Barry M., 1999. The emerging underclass in the russian federation: income dynamics, 1992-1996. Economic Development and Cultural Change 4, 803-829.

Magnani, Elisabetta, Rammohan, Anu, 2009. Ageing and the family in Indonesia: an exploration of the effect of elderly care-giving on female labor supply. Journal of Income Distribution 18, 110-130.

McColluch, Neil, Baulch, Bob, 2000. Simulating the impact of policy upon chronic and transient poverty in Rural Pakistan. Journal of Development Studies $36,100-130$

Mendola, Mariapia, Carletto, Gero, 2012. International migration and gender differentials in the home labour market: evidence from Albania. Labour Economics 19, 870-880

Micklewright, John, Ismail, Suraiya, 2001. What can child anthropometry reveal about living standards and public policy? An illustration from Central Asia. Review of Income and Wealth 47, 65-80.

Namazie, Ceema, Sanfey, Peter, 2001. Happiness in transition: the case of Kyrgyzstan. Review of Development Economics 5, 392-405

Paci, Pierella, 2002. Gender in Transition. World Bank, Washington, DC.

Parpiev, Ziyodullo, Yusupov, Kakhramon, 2011. Testing household economies of scale in Uzbekistan. Eurasian Journal of Business and Economics 4, 25-51.

Parpiev, Ziyodullo, Yusupov, Kakhramon, Yusupov, Nurmukhammad, 2012. Outlay equivalence analysis of child gender bias in household expenditure data: evidence from Uzbekistan. Economics of Transition 20,549-567.

Pavin, Melinda, Nurgozhin, Talgat, Hafner, Grace, Yusufy, Farruh, Laing, Richard, 2003. Prescribing practices of rural primary health care physicians in Uzbekistan. Tropical Medicine \& International Health 8, 182-190.

Radeny, Maren, van den Berg, Marrit, Schipper, Rob, 2012. Rural poverty dynamics in Kenya: structural declines and stochastic escapes. World Development $40,1577-1593$

Rhoe, Valerie, Babu, Suresh, Reidhead, William, 2008. An analysis of food security and poverty in Central Asia - case study from Kazakhstan. Journal of International Development 20, 452-465. 
Rodriguez, Edgard R., Tiongson, Erwin R., 2001. Temporary migration overseas and household labour supply: evidence from Urban Philippines. International Migration Review 35, 709-725.

Sari, Nazmi, 2004. Consumer spending for pharmaceuticals and its implications for health care financing: the case of Kazakhstan. Eastern European Economics 42, 43-55.

Savastano, Sara, Scandizzo, Pasquale L., 2009. Optimal farm size in an uncertain land market: the case of Kyrgyz Republic. Agricultural Economics 40, 745-758.

Shahriari, Helen, Danzer, Alexander, Giovarelli, Renee, Undeland, Asyl, 2009. Improving Women's Access to Land and Financial Resources in Tajikistan World Bank Report. World Bank, Washington, DC.

Shemyakina, Olga, 2011. The effect of armed conflict on accumulation of schooling: results from Tajikistan. Journal of Development Economics 95, 186-200.

Vella, Francis, 1994. Gender roles and human capital investment: the relationship between traditional attitudes and female labour market performance. Economica 61, 191-211.

Verme, Paolo, 2000. The choice of the working sector in transition: income and non-income determinants of sector participation in Kazakhstan. Economics of Transition 8, 691-731.

Verme, Paolo, 2001. Transition Recession and Labour Supply. Ashgate, Aldershot.

Verme, Paolo, 2006. Pro-poor growth during exceptional growth: evidence from a transition economy. European Journal of Comparative Economics 3, 3-14.

Verme, Paolo, 2010. A structural analysis of growth and poverty in the short-term. Journal of Developing Areas 43, 19-39.

Zamarro, Gema, 2011. Family Labor Participation and Child Care Decisions. The Role of Grannies, RAND Labor and Population Working Paper. RAND Labor and Population, Santa Monica. 